\title{
A Model of Religious Moral Approach for Peatland Ecosystem Restoration in Indonesia
}

\author{
Gugah Praharawati $^{1,6}$, Fachruddin Majeri Mangunjaya ${ }^{1,2^{*}}$ Hendra Maujana Saragih $^{2,3}$, Aos Yuli Firdaus ${ }^{3}$, \\ Taufik Mei Mulyana', Fauziah IImi', Muhammad Zulham², Haris Gunawan', Suwigya Utama ${ }^{4}$, Ernawati \\ Sinaga $^{5}$
}

\begin{abstract}
${ }^{1}$ Center for Islamic Studies Universitas Nasional, J1. Sawo Manila, Pejaten, Ps Minggu, Jakarta, Indonesia 12520 ${ }^{2}$ Graduate School, Universitas Nasional, Jl. Harsono RM, Ragunan, Ps Minggu, Jakarta, Indonesia 12550

${ }^{3}$ Faculty of Political Science Universitas Nasional Jl. Sawo Manila, Pejaten, Ps Minggu, Jakarta, Indonesia 12520

${ }^{4}$ Peatland Restoration Agency (BRG), Gedung Sekretariat Negara Lantai 2, Jl. Teuku Umar 10, Jakarta, Indonesia 10350

${ }^{5}$ Faculty of Biology Universitas Nasional, Jl. Sawo Manila, Pejaten, Ps Minggu, Jakarta, Indonesia 12520

${ }^{6}$ Graduate School, Conservation of Tropical Biodiversity, Faculty of Forestry and Environment, IPB University, Bogor, Indonesia 16680
\end{abstract}

\section{Received December 9, 2020/Accepted July 14, 2021}

\begin{abstract}
Efforts to conserve peatlands and prevent forest fires are inseparable from human awareness and behavior. This study aims to find a model for a religious, moral approach by the clerics in supporting the implementation of peatland restoration. The study was carried out in designated Muslim locations with trained clerics. The farmers surveyed also have experienced by the Peatland Restoration Agency (BRG) programs: i.e., physical support, such as a canal dam program and demonstration plot of agriculture without burning (PLTB). The methods used combine quantitative surveys with a Likert scale to explore attitudes, subjective norms, perception, intention, and their impact on behavior. The results obtained show that the community religious leaders can be an important trigger in encouraging the movement. In the model, visible subjective norm $(S N)$ variables contribute directly to intention by $23 \%$. Perceived behavior control (PBC) directly has a positive and significant effect on intention 53\% ( $p$-value). This means the individual, in making a decision and intention to participate, is a factor that has a broad impact on the community and gives a positive value of $53 \%$ (good enough) on the intention. The individuals' decisions to participate in peatland conservation are prompted by perception of having a wide impact on the community.
\end{abstract}

Keywords: conservation, clerics, peatland restoration, muslim, behavior change

*Correspondent author, e-mail:fmangunjaya@civitas.unas.ac.id, tel.+62-217806700 fax. +62-217802718

\section{Introduction}

Indonesia has, in total, $149,056 \mathrm{~km}^{2}$ of peatlands. These are located in Kalimantan (28-32\%), Sumatera (34-43\%), and Papua (25-38\%) (BRG, 2016; Harrison et al., 2019). The nation has been challenged with significant damage of its forest and peatlands caused by wildfire just in the past two decades. The latest fires originating from peatlands in Indonesia are alarming. In 2015, for example, 2.6 million ha were burned in eight provinces in Sumatera, Kalimantan, with economic losses reaching USD16 billion. This sum is twice as much as the budget spent on reconstruction after the Aceh tsunami (BRG, 2016; Pribadi \& Kurata, 2017). These 2015 fires in Indonesia are estimated to have contributed roughly 1,750 million metric tons of carbon dioxide equivalents $\left(\mathrm{mtCO}_{2} \mathrm{e}\right)$ (The World Bank, 2016). This disaster was indeed triggered by the distribution of el-Nino years in 2015 (Miettinen et al., 2017).

In an effort to overcome the problem, the goverment of Indonesia established the Peatland Restoration AgencyBadan Restorasi Gambut (BRG). The agency received a Presidential mandate to restore peatlands in 7 provinces: Riau, Jambi, South Sumatera, South Kalimantan, West Kalimantan, Central Kalimantan, and Papua (BRG, 2016).
This decision was made under Presidential Order (Kepres) in response to the negative effect on peatlands in the previous years.

The previous research found similar evidence that the peatland damage in Riau was also caused by human behavior (Carmenta et al., 2017). Therefore, the effort to change human behavior is an important step, besides physical and mechanical intervention in handling the peatland, such as canal blocking, seedling transplantation, and promotion of seed dispersal (Dohong, 2018). The peat restoration program is an integrated effort involving communities in the peatland area as well as various efforts to restore the peat ecosystem, so that the hydrological condition, structure, and functions are recovered based on the purpose of its establishment (BRG 2016; Dohong, 2018; Harrison et al., 2019).

However, the main cause of forest degradation, negative human behavior, is challenging because it constitutes the root of the envonmental crisis (Rare \& Behavioral Insight Team, 2019) and White $\operatorname{Jr}(1967)$ mentions it as being related to their religions, however, the effort of greening the religions is the way that we have to work together with religious actors, and (Veldman et al., 2014; Mangunjaya, et al., 2015). Our “... secular approaches have been insufficient 
because most of them ignore the fact that, ultimately, the environmental crisis as a whole is a spiritual and moral crisis," says Sponsel (2020), in his new edited book: "Religious Environmental Activism in Asia."

This research aim is to understand the effectiveness of community imams (clerics) in involving their communities by preaching about peatland restoration and religious edicts (fatwas) regarding the prohibition of peatland burning. It is realized that religious leaders and religious and traditional leaders can be agents of change in influencing behavior change (Mangunjaya, 2011; Mangunjaya \& McKay, 2012; Mangunjaya \& Praharawati, 2019).

In 2018, BRG together with the Universitas Nasional and the Indonesian Ulama Council (MUI) trained 163 imams from several backgrounds such as teachers, community leaders, and traditional leaders (Mangunjaya, 2018). In their training activities, they were provided with Islamic ethics for nature as well as an Islamic moral ruling (fatwa), especially MUI fatwa Number 30/2016 about the Law on the Burning of Forests and Land and their Management. A fatwa is a non binding law or legal opinion on a point of Islamic law (shari'a) given by a qualified jurist in Indonesia by the Fatwa Council of Indoneisa MUI in response to a question posed by a private individual, judge, or government (Gade, 2015). The fatwa can be a basis of moral motivation because state regulations alone are not enough to provide motivation for preventing forest fires, and this fatwa instrument has been proven to assist the development program actions undertaken by the government (Mangunjaya \& Praharawati, 2019). In training other than the Peat Restoration Module, the preachers were also provided with a Friday sermon that expands on peat preservation and restoration material to be conveyed to the public (MUI, 2018; Prabowo \& Mangunjaya, 2018). The training included capacity building for the clerics in extending their understanding of Islamic ethics to the natural world (Khalid, 2019) as well as providing recommendations for further implementation.
The purpose of this study is to find out the impact of the religious moral approach in moving the community to participate in the peat restoration program. It tests several parameters related to the capability of the propagator in moving the community through parameters; attitudes (people's attitudes to peat restoration programs), subjective norms (the extent to which community's subjective norms play a role in peat preservation and perception), people's perceptions about peat restoration programs, intentions (intentions to be involved in peat restoration) and their impact on behavior (behavior change or community action in preserving peat forest). This research was conducted by extending the theory of planned behavior (TPB) by Ajzen, a theory that links one's beliefs and behavior to perceived behavioral control (PBC), which together shape an individual's behavioral intentions and behaviors (Ajzen, 1991; Fishbein \& Ajzen, 2010). This research also aims to bring up some factors that are determinants of changes in community behavior in an effort to support better policies and develop a synthesis of participation models and roles in the community using structural equation modeling (SEM) (Kaplan, 2008; Dachlan, 2014).

\section{Methods}

Study area The study was conducted in two provinces: West Kalimantan and Riau, Indonesia in AugustSeptember 2019. The villages sampled were villages that had experienced intervention by BRG. The West Kalimantan location was in the Kubu Raya Regency consisting of five villages: Kuala Dua, Tebang Kacang, Sungai Rasau, Jungkat, and Sungai Bakau Besar. The research location in Riau Province, Siak Regency covers four villages: Buantan Lestari, Tuah Indrapura, Jatibaru, and Sungai Linau (Figure 1).

The determination of the sample villages was done deliberately to include places where there were clerics who had participated in capacity building in 2018. Farmers and demonstration plots were chosen by matching and ensuring

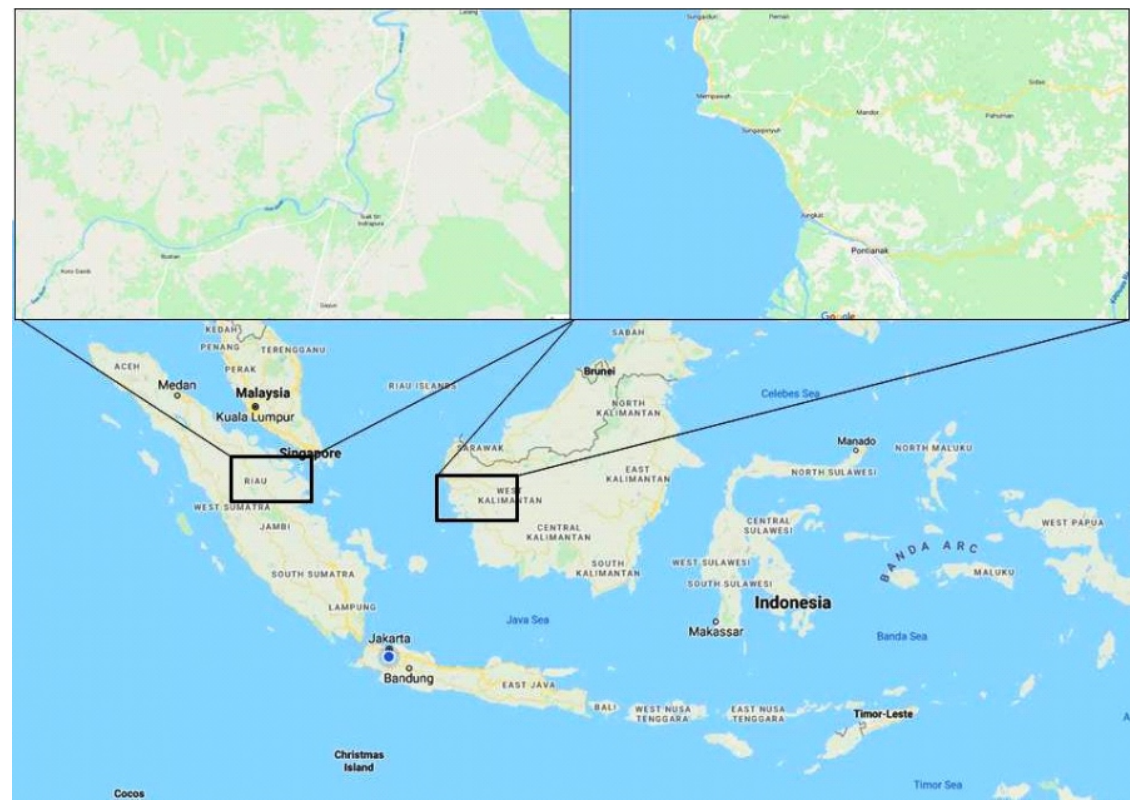

Figure 1 Study areas. (1) Riau Province and (2) West Kalimantan Province, Indonesia. 
the villages which were equally represented. The total sampling number was 277 respondents, a quantitative design with a survey of respondents using questionnaires with attitude variables: subjective norms, PBC, intention, and behavior, using a Likert scale (Table 1). We used a form containing positive and negative statements: positive statements were given values $4,3,2$ to 1 , and negative statements were given values 1,2,3 to 4 . In addition, in-depth interviews were also conducted with selected respondents to obtain a qualitative picture with narrative explanations. Furthermore, respondent data was also analyzed using structural equation modeling (SEM) (Kaplan, 2008). This technique is the combination of factor analysis and multiple regression analysis, and it is used to analyze the structural relationships between measured variables and latent constructs.

Data collection This study targeted purposive sampling locations, five villages in two provinces that have experienced intervention by BRG in Riau and West Kalimantan. The villages studied were sorted using criteria such as: villages with mosques, preachers who have participated in training, farmers, and communities with demonstration plots of sustainable agriculture conducted by the BRG program. The questions given in this research use decisive indicators of the impact on the community to see the extent of what is happening in the community in terms of preserving the peatland habitat and the impact of what is taught by the preachers when delivering religious moral messages, especially MUI fatwa Number 30/2016 about the prohibition of burning forests and land, which is expected to be a determinant of community intentions and their impact on behavior in the conservation of the peat habitat.

Research framework The results of this research are expected to show a picture in terms of community efforts and intentions to sustainably maintain peatland areas. The study was conducted using quantitative and qualitative approaches. The quantitative approach was carried out using a questionnaire, and qualitative instruments were carried out through in-depth interviews with both preachers and community representatives. Expected outputs were decreasing peat forest fires and increasing community participation in peat restoration.

The research design depicted in Figure 2 is consistent with Ajzen's (1991) theoretical framework with four variablesattitude, subjective norm, $\mathrm{PBC}$, and intentionto predict a positive relationship with attitude to behavior (PBC), which is also expected to strengthen behavioral intention.

Table 1 Supporting indicators and research variables

\begin{tabular}{ll}
\hline Variables & Indicators \\
\hline Attitude & AT1 = Attitude toward peatland restoration (4 indicators) \\
& AT2 = Management of land without burning (3 indicators) \\
& AT3 = Community training (2 indicators) \\
& AT5 = Clerics preaching for peatland (2 indicators) \\
\hline Subjective norm & SN1 = Most of the population intends to conserve peat \\
& SN2 = Most people who are important to me agree to conserve peat \\
& SN3 = Religious leaders and community leaders in my village encourage \\
& peatland conservation \\
\hline Perception of behaviour control & PBC = I am participating in peatland conservation and my actions have a \\
& wide impact on the community \\
& PBP = The decision to conserve peatlands depends on myself \\
\hline Intention & IN1 = Intend to farm environmentally friendly peatlands \\
& IN2 = Intend to remind people \\
& IN4 = Intend to participate in peat restoration activities \\
\hline Behavior & BH1 = Farming activities managing peatlands \\
& BH2 = Village community behaviour in managing peatlands \\
& BH3 = Protecting peat environments from fire hazards \\
\hline
\end{tabular}

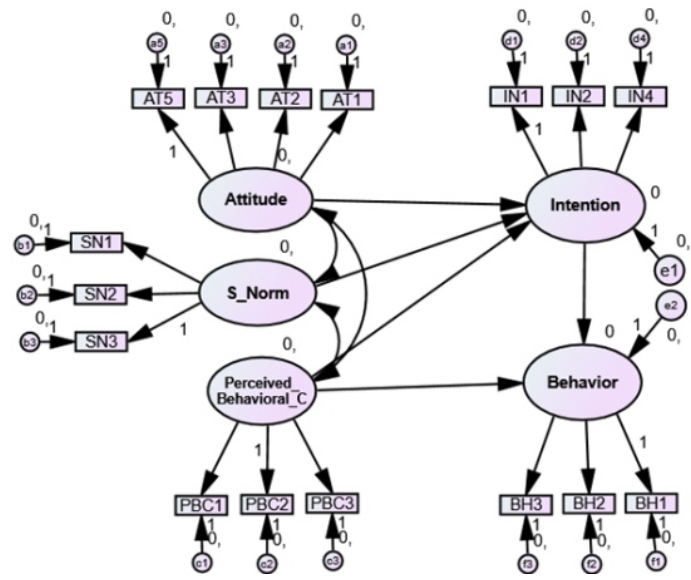

Figure 2 Path diagram modifications to the design of the research model by adopting the theory of the planned behavior (Ajzen, 1991). 
The theory of planned behavior (TPB) will provide an overview that human behavior can change for the better if it is influenced by several factors: (1) attitude, (2) subjective norms, and (3) behavior control (PBC) as a determining dimension of intention and behavior someone. The approach in this theory is known to predict individual behavior more specifically. The intention and behavior of individuals are also motivated by education (Ajzen \& Sexton, 1999).

The fire fatwa that is heard by the public is an information that expected to be effective in influencing, attitudes, subjective norms and community PBC in making decisions to intend and behave not to burn land. The more frequent dai provides da'wah on fatwa Number 30/2016 regarding the law of forest and land burning and its control, it is hoped that there will be an increase in the understanding of the community to conserve peatlands. The role of religious leaders in disseminating fatwas also has an important role in social life.

Awareness and training conducted by the Peatland Restoration Agency (BRG) has an important role in changing people's perceptions of using peatlands to be more productive and can increase community economic income, namely by training people to manage and use peatlands for plantations without having burning or using land.

Attitude is a positive or negative belief that leads to displaying a certain behavior. This belief is called a behavioral belief. An individual will tend to display a certain behavior when he/she evaluates it positively. Attitudes are determined by individual beliefs about the consequences of displaying a behavior (behavioral beliefs), weighed based on the results of an evaluation of the consequences (outcome evaluation). These attitudes are believed to have a direct influence on behavioral intentions and are associated with subjective norms and perceived behavioral control.

Subjective norms are also assumed to be a function of beliefs specifically where someone agrees or disagrees to display a behavior. Trusts included in subjective norms are also called normative beliefs. An individual will intend to display a certain behavior if he/she perceives that other important people think that he/she should do it. Another important person can be a partner, best friend, doctor, etc.

Table 2 Number of respondents $(\mathrm{n}=277)$

\begin{tabular}{lcc}
\hline \multicolumn{1}{c}{ Village names } & Frequency & $\begin{array}{c}\% \text { of } \\
\text { population } \\
\text { sampling }\end{array}$ \\
\hline West Kalimantan Province & & \\
\hline Kelapa Dua & 25 & 9 \\
Tebang Kacang & 20 & 7.2 \\
Jungkat & 45 & 16.2 \\
Sungai Bakau Besar Darat & 29 & 10.5 \\
Sungai Rasau & 29 & 10.5 \\
\hline Subtotal & 148 & 53.4 \\
\hline Riau Province & & \\
\hline Buantan Lestari & 26 & 9.4 \\
Jati Baru & 32 & 11.6 \\
Sungai Linau & 48 & 17.3 \\
Tuah Indra Pura & 23 & 8,3 \\
\hline Subtotal & 129 & 46.6 \\
Total & 277 & 100 \\
\hline
\end{tabular}

This is known by asking respondents to judge whether the other important people were likely to agree or disagree if they display the intended behavior.

PBC brought in by Ajzen (1991) refers to the degree to which an individual feels whether or not a behavior which is intended is under his control. People tend not to form a strong intention to display a certain behavior if they believe that they do not have the resources or opportunity to do so even though they have a positive attitude, and they believe that other people who are important to them will approve it. PBC can influence behavior directly or indirectly through intention. The direct path from PBC to behavior is expected to arise when there is harmony between perceptions of control and the actual control of a person over a behavior.

\section{Result}

Demography Demographically, this study obtained the samples as shown in Table 2 .

This research was conducted in August and September 2019 in nine villages, consisting of five villages from West Kalimantan Province and four villages from Riau Sumatera Province. The number of respondents involved was 277 respondents, consisting of 148 respondents (53.4\%) from West Kalimantan and 129 respondents $(46.6 \%)$ from Riau Province. The number of samples ranged from $7.217 .3 \%$ of the total village population studied (Table 2).

In-depth interviews revealed that the villages that were targeted by the survey, both in West Kalimantan and Riau, were peat villages that had developed in the 1980s. Some of the villages visited were villages that bloomed during the transmigration program initiated by the President Soeharto Government. Based on survey results, $82 \%$ of respondents claimed to be Javanese and Madurese (Figure 3). Javanese and Madurese are well-known for their diligence and hard work in business, so that they become successful. This survey revealed that the population we met was the first generation mixed with the second generation who grew up in peatlands, opening new villages due to the village transmigration program in newly formed villages, which have developed in the last 30 years.

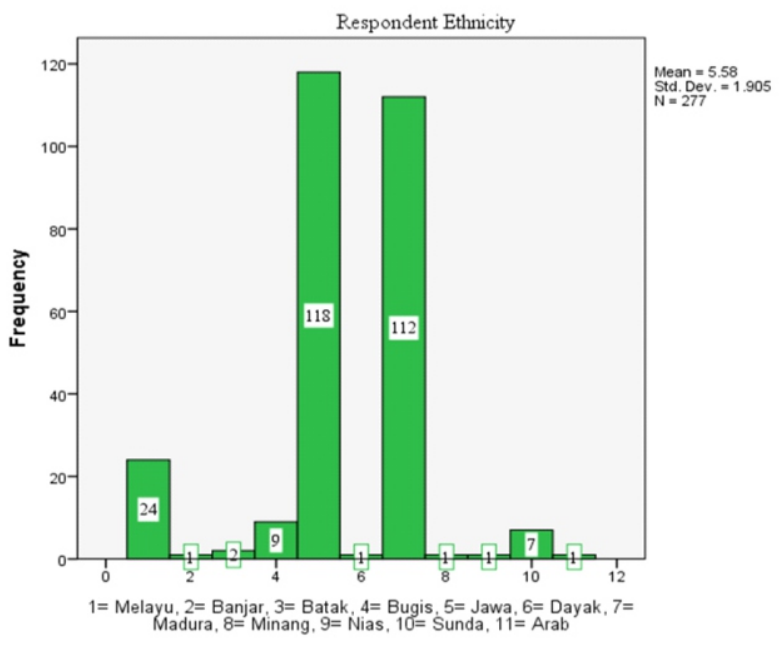

Figure 3 Ethnicity of respondents. 
Clerics preaching on fatwas in community This survey questions the efforts of trained clerics in conveying messages related to peatland issues. As shown in Figure 4, the intensity of preaching about Islamic ethics and fatwas on the preservation of creation shows that 113 respondents $(40.8 \%)$ sometimes receive this information, while 103 respondents $(37.2 \%)$ answer often (often) hear from the clerics. The answers are often (often) below, indicating that the dai has often conveyed his preach on fatwas to the public.

The above percentage shows that the preaching of clerics in conveying about peatlands and Islamic ethics is not yet perfect because there are still answers from the community who say they do not know (never). This may be because: their knowledge of peat and/or relevant sources of information is limited. Two resource persons released by the Indonesian Ulama Council (MUI), namely the Clerics Capacity Empowerment, and Friday's Sermon on Peat Conservation and Restoration (MUI, 2018; Prabowo \& Mangunjaya, 2018) need to be supported by other materials or enrich the clerics knowledge. Therefore, it is necessary to encourage and intensify efforts to conduct socialization or preaching on peatland.

There are actually many factors that need to be considered to explain why statements do not conform to reality although BRG has conducted training and guidance as well as provided community facilitators. It could be that the public does not understand, or the preachers are not effectively or comprehensively delivering their messages. In addition, it can take time to see changes in people's behavior. There should be appropriate actions that can touch their hearts in order to stimulate positive action. Another factor is also that the opening up of forest and peatland for productive cultivation requires high financial costs, so that people are more likely to use fire, which is fast and cheap.

According to the graph of respondents, the ones who said that burning forests is haram 40.8\% answered 'sometimes', and $37.2 \%$ answered 'often' (Figure 4). The community's response about how effective it was to communicate the fatwa on forest and land fires was that it was 'very effective' (16.6\%), 'effective' (37.9\%), and 'don't know' (35.4\%) (Figure 6).

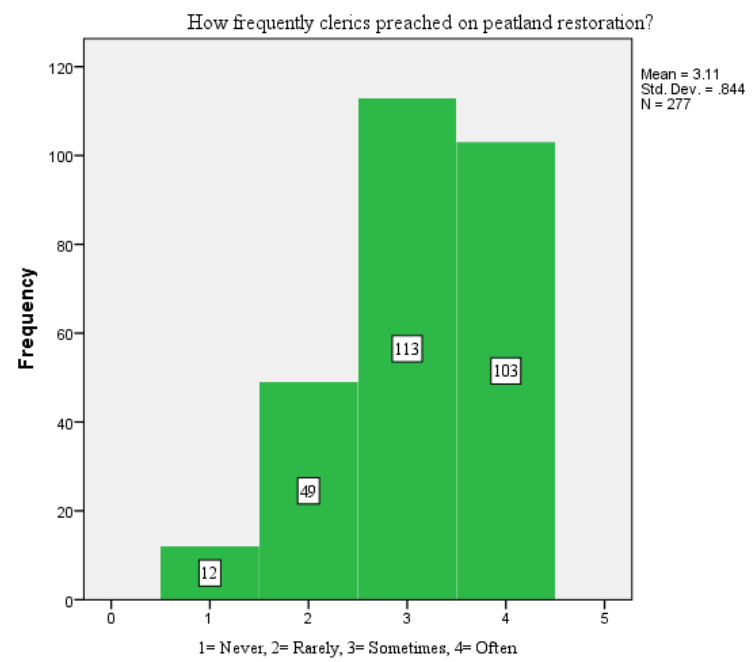

Figure 4 Preaching about fatwas on peatlands restoration.
The public perception that the communication of the fatwa was 'effective' or even 'very effective' is crucial, in that there is optimism that the fatwa factor can be a trigger for change. On the other hand, there were those who expressed doubt that they might not have heard that the fatwa was delivered to the public, which indicated that the fatwa was not well disseminated. The rest of respondents answered, did not know about the fatwas (35.4\%).

This means that the clerics very often discount the importance of the MUI fatwa in preserving the environment and ecosystem in the midst of the congregation and in the various studies where the positive impact of the da'wah delivered to the public has a strategic position and can create conditions that are very conducive to society. If they continue to cut down the trees in the forest carelessly even further, it is better for the clerics training to be continued, so that this important message can get through to the public who has not learned it yet. It can then become an important example for the sustainability of the ecosystem and Islamic values widespread among the people, until there are no more painful forest fires, and the peatland habitat is free from all their effects.

Figure 5 explains how the role of the preacher in delivering fatwas, and the respondent says never, rarely, sometimes and often. 7(2.5\%) never, 51(18.4\%) rarely, $91(32.9 \%)$ sometimes and $128(46.2 \%)$ often. Its meaning that $97.47 \%$ of active preachers conveyed the prohibition of burning land. The fatwa says, among others:

"The burning of forests and land that can cause damage, pollution, harm to other persons, adverse health effects, and other harmful effects, is religiously forbidden (haram)".

So, the key factors of the approach were, is there still burning being conduct by community after this fatwa delivered? Figure 6 show whether the MUI fatwa Number $30 / 2016$ on forest fires has an important role for the community, and how they rate its effectiveness: the 'effective' answer is $105(37.9 \%)$, 'very effective' is 46 $(16.6 \%)$, and 'quite effective' is $11(2.5 \%)$, not effective is 2 $(0.7 \%)$ and 'don't know' is $98(35.4 \%)$.

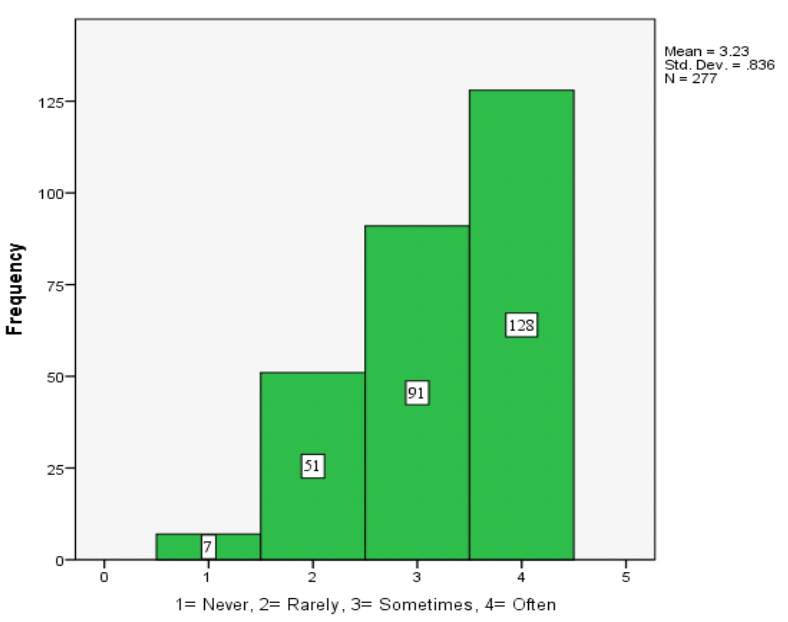

Figure 5 How often clerics delivered the fatwa? 
Determining factor of the models In our survey, we asked questions to explore how villagers behave in managing peatlands with a negative proposition on whether farmers still "use fire" to clear land? In the bar chart below (Figure 7), the highest answer is 'rarely' $45.8 \%$, 'sometimes' $21.3 \%$, and 'often' $8.7 \%$, 'never' $24,2 \%$, (67 respondents out of 277$)$. The remaining 211 are people who still used fire, 'rarely' 'sometimes' or 'often'.

When asked in in-depth interviews, this behavior was seen to be based on the community's need to obtain cheap fertilizer from the results of burning land rather than making compost manually. However, when asked whether fires to clear land could ignite forest fires, they generally did not admit it. The reason is that hotspots often appear during the dry season, and they have difficulty extinguishing them due to the lack of water.

On the other hand, farmers have also used their land, which was partially burnt, as agricultural land for BRGassisted ginger cultivation. That is, the community also utilizes the BRG program for alternative farming activities, but does not immediately abandon the burning activity (TEMPO, 2020).

Influential figures in the community Leaders or influential figures in the community can be an important trigger in encouraging a movement. This research also tries to map out who exactly respected figures are in the community system, especially in peat villages where there is intervention by

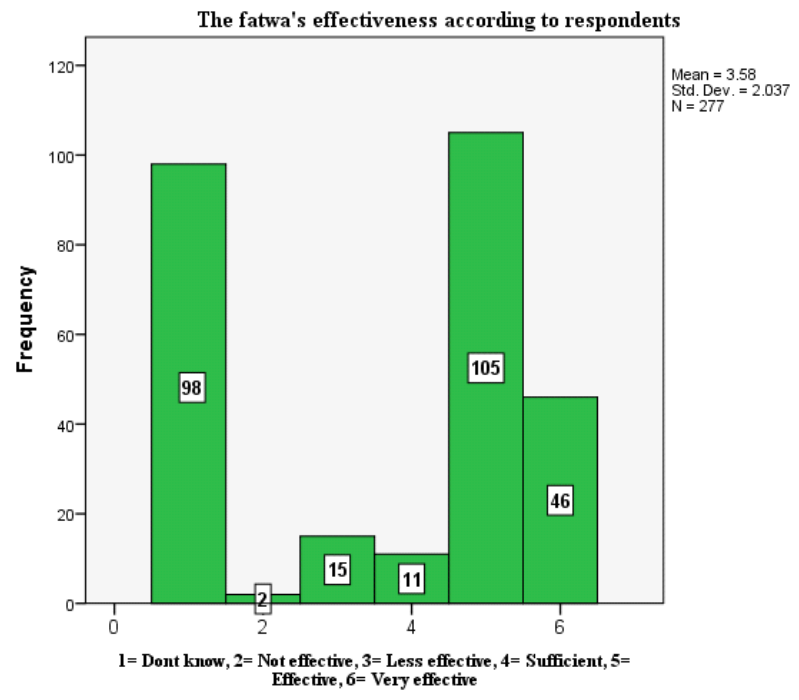

Figure 6 Was the fatwa effective in halting forest burning?
BRG. The table shows that the community chose to obey the governments $(39.4 \%)$, clerics $(24.9 \%)$, and family $(24.2 \%)$. The community leaders get an $11.7 \%$ confidence level (Table 3).

Analysis model of the effectiveness of the preaching in peatland In testing the effectiveness of the peat $d a^{\prime} i$ program, there are stages in the form of assuming data normality by looking at the multivariate $\mathrm{CR}$ (critical ratio) value with a range of \pm 2.58 at the $1 \%$ significance level $(\alpha=1 \%)$ and \pm 1.96 at the $5 \%$ significance level $(\alpha=5 \%)$ where the value of kurtosis is $17.77>1.96$, so that all variables are not normally distributed (0). In this study, the multivariate data outlier assumption test was not carried out, because in the behavior test using an ordinal scale, data normality testing did not need to be done, because by nature ordinal data is not quantitative data that must meet the normality assumption (Santoso, 2015).

Overall goodness of fit index testing This test is carried out to see whether the model fits. Models that meet the construct validity are not enough. The usual size/index for assessing model fit is the Chi-square and its $p$-value, i.e., RMSEA, GFI, CFI, or IFI. In general, to avoid misinterpretation of the fit value of the model, there are several limitations, namely:

1. The price index of a model fit reflects the overall model fit (average) and is not to be interpreted for each sub-model or parts of the model.

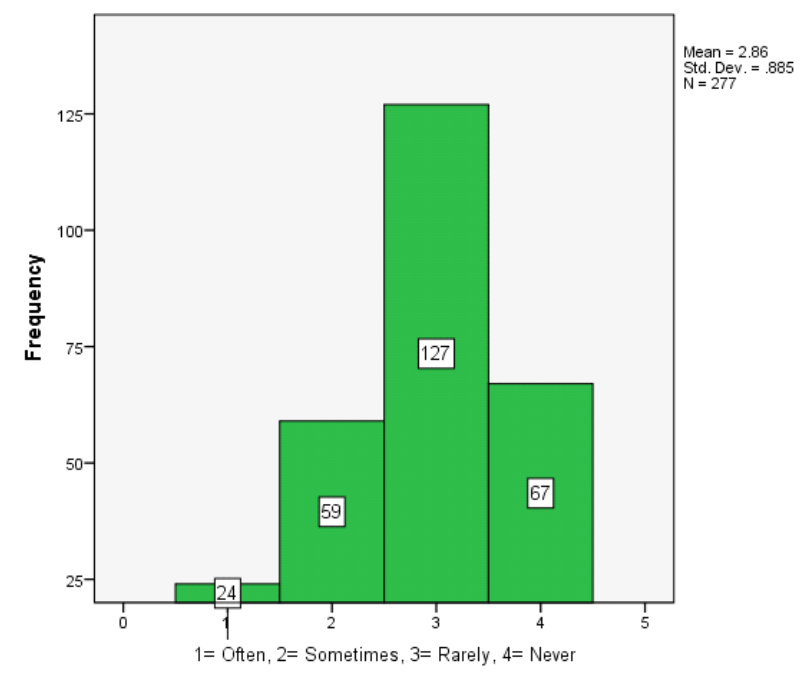

Figure 7 Determinants of fire from negative statements.

Table 3 Community obedience to leadership

\begin{tabular}{lcc}
\hline \multicolumn{1}{c}{ Leadership } & Frequency & Proportion (\%) \\
\hline Governments & 109 & 39.4 \\
Clerics & 69 & 24.9 \\
Family & 67 & 24.2 \\
Community leaders & 32 & 11.7 \\
\hline
\end{tabular}


2. A single fit index only reflects one aspect of the model fit, so if a certain fit index value is good, it does not necessarily indicate a good overall model fit.

3. The fit of the model does not at all indicate whether the model and the theoretical results obtained are theoretically meaningful. This means that the model fit only shows the suitability of the model being built. A better model fit does not mean that the predictive ability of the model is getting better because it is still very possible that there are still large measurement and structural errors. The results of the full model feasibility test in this study can be seen in Table 4 and Table 5 .

From the results described in Table 4, all GOF test results do not show model fit (shows in model 1, Figure 8), so it is necessary to do modification indices by carrying out a series of testing processes to get a better or fit model 2 (Figure 9), namely by correlating between measurement errors. This test is performed to reduce the Chi-square value, because the smaller the value the better. Figure 9 shows the results after modification indices.

Based on the feasibility test of the first model (the structural model goodness of fit index is presented in Table 4), the Chi-square index is the most basic measure of fit index and is a measure of model suitability in SEM. Thus, it can be concluded that this model is not good enough to test the behavior of the community in the intervention village. So that the indices are modified, so that the model is good (Figure 9 and Table 5).

Table 4 Overall goodness of fit index in diagram model 1

\begin{tabular}{llll}
\hline GOF index & Cut of value & Value & Note \\
Chi-square & The smaller the better & 217.516 & Positif \\
\hline CMIN/DF & $217.516 / 96$ & 2.266 & Not fit \\
Probability & $\geq 0.05$ & 0.000 & Not fit \\
RMSEA & $\geq 0.08$ & 0.068 & Fit \\
CFI & $\geq 0.9$ & 0.900 & Fit \\
TLI & $\geq 0.9$ & 0.875 & Poor fit \\
IFI & $\geq 0.9$ & 0.902 & Fit \\
NFI & $\geq 0.9$ & 0.838 & Poor fit \\
RFI & $\geq 0.9$ & 0.797 & Poor fit \\
\hline
\end{tabular}

Table 5 Overall goodness of fit index in modification indices model 2

\begin{tabular}{llll}
\hline GOF index & Cut of value & Value & Note \\
Chi-square & The smaller the better & 124.332 & Positif \\
\hline CMIN/DF & $86.667 / 78$ & 1.111 & Good fit \\
Probability & $\geq 0.05$ & 0.235 & Good fit \\
RMSEA & $\geq 0.08$ & 0.020 & Good fit \\
CFI & $\geq 0.90$ & 0.993 & Good fit \\
TLI & $\geq 0.90$ & 0.989 & Good fit \\
IFI & $\geq 0.90$ & 0.993 & Good fit \\
NFI & $\geq 0.90$ & 0.935 & Good fit \\
RFI & $\geq 0.90$ & 0.900 & Good fit \\
\hline
\end{tabular}

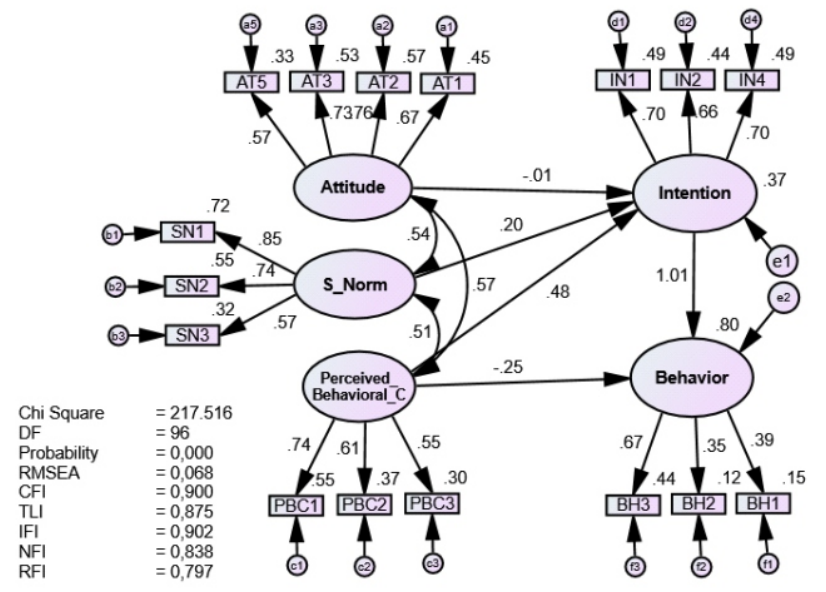

Figure 8 Diagram model 1.

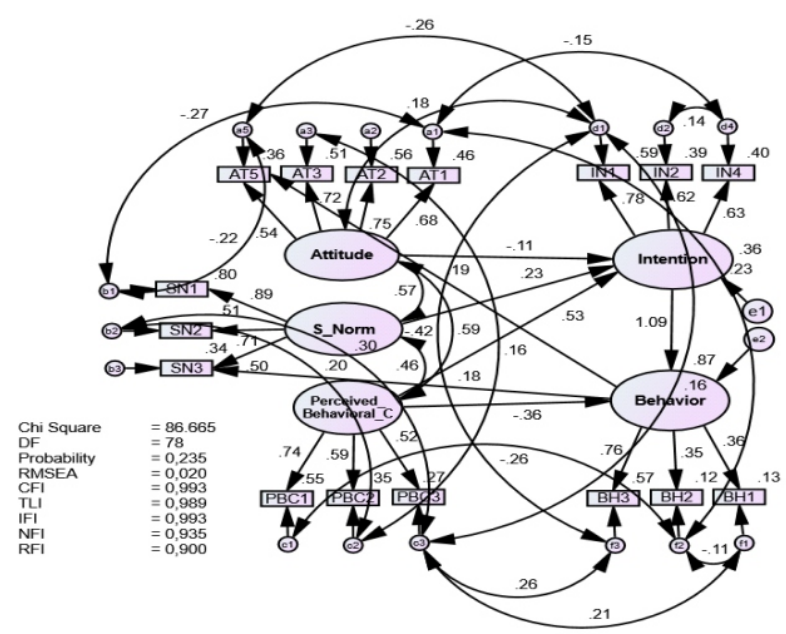

Figure 9 Modification indices model 2. 
The model obtained has the following measurements: Chi-square value $=124.332 ; \mathrm{Df}=78 ; p$-value $=0.235$; RMSEA $=0.020$. Test validity and reliability of constructs: Simultaneously the validity of the constructs is indicated by $\mathrm{CR}>0.7$, which means that all variables are in accordance with the CR measure, but there are only subjective norm variables that also meet the requirements of the AVE measure (Table 6). Based on these results, for other latent construct variables it can still be said to be quite good although there are still many error factors that affect and are not included in this study. So that overall the data is still reliable to be used as information in the next analysis (Dachlan, 2014).

The results of data processing and the construct of the religious (Islamic) approach model in peat restoration efforts are illustrated as shown in Table 7.

The results in Table 7 answer the proposed hypothesis: 1) Direct attitude does not have a positive or significant effect on Intention ( $p$-value); 2) S_Norm directly has a positive and significant effect on intention; 3) PBC directly has a positive and significant effect on intention; 4) Intention directly has a positive and significant effect on Behavior; 5) PBC directly has a positive and significant effect on behavior through intention. The significant hypothesis is shown by the value of $p$-value.

Therefore, the overall equation obtained and regression models proposed for this study are shown in Equation [1] and Equation [2].

Intention $=-0.106$ Attitude $+0.227 \mathrm{~S} \mathrm{Norm}+0.533 P B C$

Behavior $=1.091$ Intention $-0.363 P B C$

Relationship of knowledge, attitudes, norms, and behavior Table 8 shows that the attitudes, norms and behavior of the community have positive values in the percentage of correlation so that the value of the relationship between behavior (PBC) with attitude $(58.8 \%)$, behavior (PBC) with norms is $45.5 \%$, norms with attitudes are $56.9 \%$. This shows a moderate level in the relationship between variables, so that interventions that involve the community in maintaining peat need to be improved by increasing understanding of peat conservation periodically to achieve good categories.

\section{Discussion}

Attitude does not have a positive and significant effect on intention ( $p$-value). Meanwhile, subjective norms have a positive and significant effect on intention ( $p$-value). It means that variables are included in subjective norm elements such as "most of the population intend to conserve peatlands (SN1)", "Most people who are important to me agree to conserve peat (SN2)", "religious leaders and community leaders in my village encourage the preservation of peatlands (SN3)" have a significant influence on community intentions. In this case, the role of the community and important people close to them, including religious leaders and the community where they live, will have a strong influence in changing the community's intention to take positive action on peat restoration, including in efforts not to burn lands and forests.

In the model, the $\mathrm{SN}$ variable contributes directly to the intention (23\%). On the other hand, PBC directly has a positive and very significant effect on intention ( $p$-value). This means the individual influence in making a decision and the intention to participate have a broad impact on the community, and it gives a positive value of $53 \%$ of the intention. It is realized that individual control to participate in peatland conservation can have a wide impact on the community. PBC contributes $53 \%$ to intentions, meaning that for every $1 \%$ increase in the $\mathrm{PBC}$ rate, people's intentions will increase by $53 \%$. While PBC contributes $36 \%$ to behavior, meaning that every $1 \%$ addition of $\mathrm{PBC}$ level, the community's behavior will increase $-36 \%$, a negative value means that $\mathrm{PBC}$ has a negative effect on behavior change. If seen from the results of the significance of $\mathrm{PBC}$ has a value of $0.017<0.05$, so it can be concluded that there is a direct influence of PBC on behavior. $\mathrm{PBC}$ is an expression of an individual feeling that the appearance or failure of a behavior in question is under his/her control. Ajzen (1991) also said that a person tends not to form a strong intention to display a certain behavior if he/she believes that he/she does not have the source or opportunity to do so even though he/she has a positive attitude, and he/she believes that other people who are important to him/her will approve it.

Table 6 Quality criteria

\begin{tabular}{lcc}
\hline Variable & Composite reliability (CR) & Variance extracted \\
\hline Attitude & 0.984 & 0.456 \\
Subjective norm & 0.979 & 0.518 \\
Perceived behavior control & 0.972 & 0.392 \\
Intention & 0.968 & 0.464 \\
Behavior & 0.945 & 0.275 \\
\hline
\end{tabular}

Table 7 Analysis hypothesis

\begin{tabular}{|c|c|c|c|c|c|c|}
\hline \multicolumn{2}{|c|}{ Latent variables } & Estimates & S.E. & C.R. & $p$-value & Label \\
\hline Intention & $<-$ Attitude & -.164 & .177 & -.927 & .354 & Not significant \\
\hline Intention & $<-\mathrm{S}_{-}$Norm & .373 & .152 & 2.453 & .014 & Significant \\
\hline Intention & $<-$ Perceived behavioral control & .741 & .174 & 4.269 & $* * *$ & Significant \\
\hline Behavior & $<-$ Perceived behavioral control & -.320 & .134 & -2.392 & .017 & Significant \\
\hline Behavior & $<-$ Intention & .691 & .153 & 4.515 & $* * *$ & Significant \\
\hline
\end{tabular}


Table 8 Correlation among variables

\begin{tabular}{llll}
\hline & & Estimate \\
Perceived behavioral & $\longrightarrow$ & Attitude & .588 \\
Attitude & $\longleftrightarrow$ & S_Norm & .569 \\
Perceived behavioral & $\longrightarrow$ & S_Norm & .455 \\
\hline
\end{tabular}

PBC can influence behavior directly or indirectly through Intention. The direct path from PBC to behavior is expected to occur when there is harmony between perceptions about control and the actual control of a person over a behavior. This is where the role and presence of religious leaders and community leaders can be the key. Therefore, efforts that support community attitudes such as efforts to support peatland restoration activities supported by the government need to be optimized. On the other side, it could be supported with the capacity training for peatland management without burning, or organic farming will likely be maximizing the MUI fatwa Number 30/2016.

More importantly, the three variables revealed are related: attitudes, subjective norms, and $\mathrm{PBC}$ have a positive regression in determining individual or community behavior, and overall contributing to intentions, while intention variables contribute to behavioral actions.

The models suggested that efforts in supporting the attitude of the community in conserving peat need to be encouraged and continued, so that it can apply optimally. This survey reveals said public respect for government, so the presence of government is very important (39.4\%). The meaning of strong adherence to the government can be seen as a form of appreciation for the presence of government programs, in this case the BRG, which are quite instrumental in providing encouragement and facilitation. Then, the figure who plays second place is the preacher who can continue to be empowered to encourage the realization of behavioral actions. Thus, this trend can help reinforce behavioral actions, as illustrated in the model (Figure 8). According to Ajzen (1991) in TPB's planned behavior theory, PBC, along with behavioral intentions, can be used to predict behavioral outcomes, with the conditions that can be maintained in this hypothesis, its means that affect the intention and the decision to act are to remain constant. Intentions are also influenced by individual beliefs. Therefore, the driving factors, such as character, can influence the decision to behave.

Also obtained from this study is an overview of the important function of the clerics in the community. The study revealed that respondents gave respect mainly to the government $(39.4 \%)$, clerics $(24.9 \%)$, then family encouragement $(24.4 \%)$, and finally community leaders $(11.7 \%)$.

It can be concluded that the figure of the clerics or religious leaders is an important trigger in $\mathrm{PBC}$, after the presence of the government. That is why the capacitybuilding program in preserving peat is a religious suggestion, becoming one of the triggers for the understanding of government programs, especially BRG. However, the presence of preachers cannot be said to be a determining factor without the presence of BRG (government). The community studied is a sample taken purposely in an effort to monitor BRG intervention areas. The community stated that the presence of the government was an important factor.

The results of in-depth interviews with the respondents illustrated that now the community really understands the importance of peatlands compared to previous years, when they did not even realize they had lived for decades in the peatland area.

There are indications that the submission of preachers through religious approaches has been delivered, especially those related to the MUI fatwa Number 30/2016 on land burning. However, this effort still seems less massive at the grassroots level.

The decision of a person or community to take action or participate in peat conservation (PBC) can be driven by a positive correlation of attitudes and subjective norms. Because, according to Ajzen (1991), changes in an individual's behavior are determined by one's tendency to have strong intentions in him/herself. In this case, the proof of the theory is used as a control to see how the planned behavior changes with intervention and assistance, so that the action value will increase.

That is why the presence of driving factors increased participation in peat conservation, such as the presence of the government (BRG), religious leaders (clerics), family and community encouragement, has a positive influence on individual or community intentions in making behavioral decisions. Therefore, efforts to increase the capacity of preachers can be used as a reference among policy makers as a determining factor in the intention to encourage the behavior of peat conservation and forest fire prevention. The value of the equation found can help policy makers in determining the pattern of approach to society, as shown in Equation [1] and Equation [2].

\section{Conclusion}

The moral approach to religion has moved preachers to deliver messages related to peat conservation, and the effort can provide hope for changes in community intentions and behavior in preserving peat. The MUI fatwa has been delivered to the public although at levels that are not yet optimal, and sometimes, it is still not fully understood by the community. From the results of the interview with respondents as described, it is now clear that the community really understands the importance of peatlands compared to previous years, when they did not even realize they had lived for decades in the peatland area. It is hoped that this effort will be more massive at the grassroots level. The subjective norm factor and $\mathrm{PBC}$ which became a significant variable in this study have encouraged the emergence of intentions to behave with strong intensity. Therefore, this moral approach model can be continued for research into changes in community behavior related to peat restoration. The discovery of this model proves that the Attitude of the community does not have a positive and significant effect on Intentions, while the value of Subjective Norms directly has a positive and significant effect on Intentions. PBC directly has a positive and significant effect on Intentions, and people's Intentions directly have a positive and significant effect on Behavior. A good enough Intention can become a modality if existing activities are increased, so BRG's actions 
and programs can certainly ensure the sustainability of the peatland conservation. Changing behavior likely will be a long term result and a further study need to be conducted. If we paid attention to the modivied model Figure 9, its indicated a complex models, however except the attitude, we found the significant and positive relation of subjective norm, $\mathrm{PBC}$ to the intention, a well as PBC and intention has direct and significant influence on behavior. This model can provide an overview of the involvement of religious and moral factor in an effort to increase environmental awareness and actions to carry out conservation and restoration of peatland, particularly in Muslim communities in Indonesia. However we may conclude that this fatwa or moral (etical religious values) is not the only solution for the prevention of burning, but there are some important indicators, to work together with the clerics and religious leaders can be a supplement.

\section{References}

Ajzen, I. (1991). The theory of planned behaviour. Organizational Behavior and Human Decision Processes, 50(2), 179-211. https://doi.org/10.1016/ 0749-5978(91)90020-T

Ajzen, I., \& Sexton, J. (1999). Depth of processing, belief congruence, and attitude-behavior correspondence. In S. Chaiken \& Y. Trope (Eds.), Dual-process theories in social psychology (p. 117-138). New York: The Guilford Press.

[BRG] Badan Restorasi Gambut. (2016). Laporan tahunan BRG: Mengawali restorasi gambut Indonesia. Jakarta: BRG.

Carmenta, R., Zabala, A., Daelia, W., \& Phelpsae, J. (2017). Perceptions across scales of governance and the Indonesian peatland fires. Global Environmental Change, 46, 50-59 https://doi.org/10.1016/j.gloenvcha. 2017.08 .001

Dachlan, U. (2014). Panduan lengkap structural equation modelling. Semarang: Lentera Ilmu.

Dohong, A., Aziz, A. A., \& Dargusch, P. (2018). A review of techniques for effective tropical peatland restoration. Wetlands, 38, 275-292. https://doi.org/10.1007/s13157018-1017-6

Fishbein, M., \& Ajzen, I. (2010). Predicting changing behavior: The reasoned action approach. New York: Psychology Press. https://doi.org/10.4324/97802038 38020

Gade, A. M. (2015). Islamic law and the environment in Indonesia: Fatwa and Da'wa'. Worldviews, 19, 161-83. https://doi.org/10.1163/15685357-01902006

Harrison, M. E., Ottay, J. B., D'Arcy, L. J., Cheyne, S. M., Anggodo, Belcher, C., ... \& Frank van Veen, F. J. (2019). Tropical forest and peatland conservation in Indonesia: Challenges and directions. People and Nature, 2(1), 4-28. https://doi.org/10.1002/Pan3.10060
Kaplan, D. (2008). Structural equation modelling: Foundations and extensions (2nd ed.). Los Angeles: Sage. https://doi.org/10.4135/9781452226576

Khalid, F. (2019). Signs on the earth: Islam modernity and the climate crisis. Leicherterachire: Kube Publishing.

Mangunjaya, F. M. (2011). Developing environmental and conservation awareness through islamic teaching. Oxford Journal of Islamic Studies, 22(1), 36-49. https://doi.org/ 10.1093/jis/etq067

Mangunjaya, F. M. \& McKay, J. (2012). Reviving an islamic approach for environmental conservation in Indonesia. Worldview, 16, 286-305. https://doi.org/10.1163/ 15685357-01603006

Mangunjaya, F. M., Tobing, I. S. L., Binawan, A., Pua, E., \& Nurbawa, M. (2015). Faiths from the archipelago: Action on the environment and climate change. Worldview, 19, 103-122. https://doi.org/10.1163/15685357-01902003

Mangunjaya, F. M. (2018). The implementation of preacher (da'i) capacity-building on peatland restoration in South Kalimantan and Riau. Individual Consultant Report to UNDP. Jakarta: BRG.

Mangunjaya, F. M. \& Praharawati, G. (2019). Fatwas on boosting environmental conservation in Indonesia. Religions, 10(10), 570. https://doi.org/10.3390/ rel10100570

Miettinen, J., Shi, C., \& Liew, S. C. (2017). Fire distribution in Peninsular Malaysia, Sumatra and Borneo in 2015 with special emphasis on peatland fires. Environmental Management, 60, 747-757 https://doi.org/10.1007/ s00267-017-0911-7

[MUI] Majelis Ulama Indonesia. (2018). Khutbah Jumat: Pelestarian dan restorasi lahan gambut. Jakarta: MUI

Prabowo, H., \& Mangunjaya, F. M. (2018). Modul: Peningkatan kapasitas dai restorasi gambut. Jakarta: MUI.

Pribadi, A., \& Kurata, G. (2017). Greenhouse gas and air pollutant emissions from land and forest fire in Indonesia during 2015 based on satellite data. In IOP Conference Series: Earth and Environmental Science, 54, 012060. Retrieved from https://iopscience.iop.org/article/ 10.1088/1755-1315/54/1/012060

Rare \& The Behavioral Insight Team. (2019). Behavioral change for nature: A behavioral science toolkit for practitioners. Arlington: Rare.

Santoso, S. (2015). AMOS 22 untuk structural equation modelling: Konsep dasar dan aplikasi. Jakarta: Kompas Gramedia.

Sponsel, L. E. (2020). Religious environmental activism in Asia. Case studies in spiritual ecology. Basel: MDPI. 
https://doi.org/10.3390/books978-3-03928-647-8

TEMPO. (2020). Cegah covid-19, petani jahe tanami areal bekas lahan gambut terbakar. TEMPO. https://nasional.tempo.co/read/1324154/cegah-covid19-petani-jahe-tanami-areal-bekas-lahan-gambutterbakar

The World Bank. (2016). The cost of fire: An economic analysis of Indonesia's 2015 fire crisis: Indonesia
Sustainable Landscapes Knowledge Note 1. Jakarta: The World Bank.

Veldman, R. G., Szasz, A., \& Delay, R. H. (2014). How the world's religions are responding to climate change. London: Routledge.

White Jr., L. (1967). The historical root of our ecological crisis. Science, 155, 1203-1207. https://doi.org/10.1126/ science.155.3767.1203 